\title{
Effects of Exposure to Diazinon on the Lung and Small Intestine of Guinea Pig, Histological and Some Histochemical Changes
}

\author{
Mohamed Ibrahim Rady* \\ Department of Zoology; Faculty of Science; Al-Azhar University; Cairo - Egypt
}

\begin{abstract}
The present study aimed to evaluate the histological changes and adverse effects on the total protein and general carbohydrates in the lung and small intestine of guinea pig "Cavia porcellus" induced by the exposure to sub lethal doses of the organophosphate insecticide diazinon. Primarily, diazinon insecticide oral $L D_{50}$ was investigated after administrating orally different doses in guinea pig and was determined as $213 \mathrm{mg} / \mathrm{Kg} \mathrm{bw}$., the animals exposed to sub lethal doses of this insecticide revealed histological changes in both lung and intestine in a dose dependent manner. Also, significant decrease in the total protein and general carbohydrates in the lung and intestine were mostly observed, especially with the higher doses of the insecticide in comparison with control group.
\end{abstract}

Key words: Diazinon, Guinea pig, Lung, Intestine

\section{INTRODUCTION}

Considerable toxicity data of chemicals have been produced in the past few years. The environmental contamination with pesticides is a problem of the regional as well as world-wide importance (EPA, 1999). The toxic chemicals have been found in a variety of environmental samples including water, air and house dust, and their presence has also been noted in the tissues of non-occupationally exposed people, particularly in the adipose tissue, blood and urine (Wagner et al. 1991).

The organophosphate insecticide diazinon has agricultural, commercial, and household uses, but the household uses predominate. The crops using the most diazinon are almonds, berries, pecans, and nectarines (EPA, 1999). As most organophosphates, diazinon attaches to acetyl cholinesterase and prevent it from destroying acetylcholine causing over stimulation of the nerves (Ware, 2000). Also, diazinon and other organophosphates inhibitor numerous enzymes with molecular structure that are similar to AChE (Reigart and Roberts, 1999).

The prolonged exposure to the most commonly used agricultural pesticides increase the risk of the lung lesions, as well as cancer, in the farmers and commercial pesticide users. However, this increased risk was only significant for the prolonged exposure to diazinon, dieldrin, metalochlor and pendimethalin (Dinham, 2005). Also, the histological changes in the alimentary canal of experimental animals due to pesticides exposure have been documented (Poet et al., 2003

* Author for correspondence: <rady_prof@hotmail.com> 
and Manna et al., $2004 \mathrm{a}$ and b).

Several studies have been made on the effect of the exposure of the experimental animals, including guinea pig, to the pesticides (Purdey, 1994; Reigart and Roberts, 1999; Dede and Chike, 2000 and Dede and Dogara, 2004). However, limited information is available on the subject of detection of the exposure effects to the minor concentrations of diazinon insecticide on the internal organs of guinea pig, Cavia porcellus.

The aim of this work was to study the histological changes induced by the sub-lethal doses $(1 / 20$, $1 / 10$ and $1 / 5 \mathrm{LD}_{50}$ ) of diazinon insecticide on the lung and small intestine of guinea pig, Cavia porcellus. In addition, the changes in the total protein and carbohydrates were investigated in these tissues histochemically.

\section{MATERIALS AND METHODS}

\section{Animals}

A total of 37 male animals belonging to the common species of guinea pig Cavia porcellus were used in this study. Live and healthy specimens of these animals were collected from the markets at Cairo Province, Egypt and maintained in special cages in the animal house at room temperature for two week for acclimatization before the beginning of the experiment. The average body weight of these animals was $540 \pm 45 \mathrm{gm}$. The animals were fed ad libitum daily with green meal (alfalfa) and supplied with water.

\section{Insecticide used}

The insecticide used in this study, diazinon, was obtained from The Central Pesticides Laboratory (CPL), Ministry of Agriculture, Egypt. They were samples of that used in the fields (82\% purity). The molecular formula is: $\mathrm{C} 12-\mathrm{H} 21-\mathrm{N} 2-03-\mathrm{P}-\mathrm{S}$ and the structure formula is: $(\mathrm{C} 2 \mathrm{H} 5 \mathrm{O}) 2-\mathrm{P}(=\mathrm{S})-\mathrm{O}-$ $\mathrm{C} 4 \mathrm{HN} 2-(\mathrm{CH} 3)-\mathrm{CH}(\mathrm{CH} 3) 2$ (C4HN2 pyrimidine ring).

\section{Determination of $\mathbf{L D}_{\mathbf{5 0}}$}

A pilot study was carried out with 25 male guinea pigs (divided into five groups) to determine the minimum dose of diazinon that caused $100 \%$ death of the animals. The animals were observed for five days and a dead animal was removed immediately (an animal was considered dead after the stop of movements, loss of body reflexes and loss of the eye reflexes). The number of dead animals was recorded and the mortality rate was calculated as a percentages. $\mathrm{LD}_{50}$ was later calculated according to the equation of Behren and Karber (1953).

\section{Induction of the insecticide}

Acclimatized animals were diviced in four groups, three animals/ group and kept in separated cages. The first group was used as control, while the other three groups (TI, TII and TIII) received 1/20, $1 / 10$ and $1 / 5$ of $L_{50}$ of the insecticide, respectively, orally through gastric tube. All the cages had the same conditions mentioned at the period of the acclimatization. The animals in the treated cages as well as in control cage were observed for at least two hours after the insecticide was introduced and then were observed at time intervals. All the treated groups received eleven doses through three weeks; the dosage was day after day. After three weeks, the specimens were taken from each treated and control cages and anesthetized with ether and immediately dissected.

\section{Histological and Histochemical Investigations}

For the histological investigations, the parts of lung and small intestine from the control and the treated animals were fixed in neutral formalin. After the fixation period, the tissues were washed in the tap-water, dehydrated through a graded series of ethyl alcohol, cleared in xylene, embedded in the paraffin wax or parablast, sectioned at a thickness 5-7 microns, mounted on the glass slides and stained with haematoxylin and eosin for general morphological studies. The various slides based on the dose ranges were studied and the tissues were compared with the control, $0.9 \%$ saline injected guinea pigs.

For the histochemical investigation, polysaccharide materials were illustrated following the application of periodic acid Schiff's (PAS) technique (Huomason, 1979). For visualization of the total proteins, the mercury bromphenol blue method of Mazia et al. (1953) was applied. The study of total protein and polysaccharide materials was done using computer image analyzing system (Leica Model). The estimation of the optical density of thirty cells in each group was made. The data obtained were statistically analyzed according to Sendecor (1987). 


\section{RESULTS}

The $\mathrm{LD}_{50}$ value of diazinon in the male guinea pigs using the oral route of administration was 210 $\mathrm{mg} / \mathrm{kg}$ body weight. Table 1 illustrated the symptoms that appeared in $\mathrm{LD}_{50}$ experiment, these signs showed firstly with the calmness followed by irritability, tremor, motor incoordination, staggering and convulsion denoting neurological effects. Also, the manifestation of laboured breathing and ataxia were prominent in most groups. The oral dose of diazinon equal $270 \mathrm{mg} / \mathrm{kg}$ resulted in $100 \%$ mortality.

\section{Histological effects}

\section{Lung}

Normal structures of the lung alveoli obtained from the control guinea pig are depicted in Fig. (1 A). The normal alveoli were lined with the normal squamous cell (type I penumocytes) and secretory cells (type II penumocytes) with some macrophages. Inspected lung sections obtained from TI $\left(1 / 20 \quad L_{50}\right)$ revealed haemorrhage in different parts and increase of the dust cell within the interalveolar septa (Fig. $1 \mathrm{~B}$ ). The lung of guinea pig treated with $1 / 10 \mathrm{LD}_{50}$ of diazinon exhibited congestion in the blood vessels and infiltration of the lymphocytes in the tissues (Fig. $1 \mathrm{C})$. Also, haemorrhage and increases in both dust cells and macrophages around and within the alveoli were observed. Some alveoli were obliterated due to proliferation and hypertrophy of the alveolar cells (Fig. 1 D). The high dose of diazinon $\left(1 / 5 \mathrm{LD}_{50}\right)$ induced sever lesions in the lung of treated animals. These lesions were manifested in prevailing haemorrhage, infiltration of macrophages and mononuclear cells, oedematous tissue, pyknotic nuclei and necrotic cells (Figs. $1 \mathrm{E}$ and F).

Table 1 - The mortality rate; $\mathrm{LD}_{50}$ and signs and symptoms of diazinon insecticide toxicosis on Cavia porcellus (data collected 5 days after exposure).

\begin{tabular}{|c|c|c|c|c|}
\hline $\begin{array}{l}\text { Exp. } \\
\text { No. }\end{array}$ & Dose (mg/kg b w) & Mortality rate & $\mathbf{L D}_{\mathbf{5 0}}$ & Signs and symptoms \\
\hline 1 & 0 & 0 & \multirow{5}{*}{$\begin{array}{c}213 \\
\mathrm{mg} / \mathrm{Kg} \mathrm{b} \\
\mathrm{w}\end{array}$} & Normal \\
\hline 2 & 180 & $20 \%$ & & $\begin{array}{l}\text { - Laboured breathing, tremor and irritability (4). } \\
\text { Death (1) }\end{array}$ \\
\hline 3 & 210 & $40 \%$ & & $\begin{array}{l}\text { - Irritability and laboured breathing (3). Tremor (3). } \\
\text { Staggering and convulsion (3). Death (2) }\end{array}$ \\
\hline 4 & 240 & $80 \%$ & & $\begin{array}{l}\text { - Irritability and laboured breathing (5). Staggering } \\
\text { and convulsion (4). Death (4). }\end{array}$ \\
\hline 5 & 270 & $100 \%$ & & $\begin{array}{l}\text { - Laboured breathing (5), irritability (5), tremor (5), } \\
\text { staggering (4) and convulsion (5). Death (5). }\end{array}$ \\
\hline
\end{tabular}




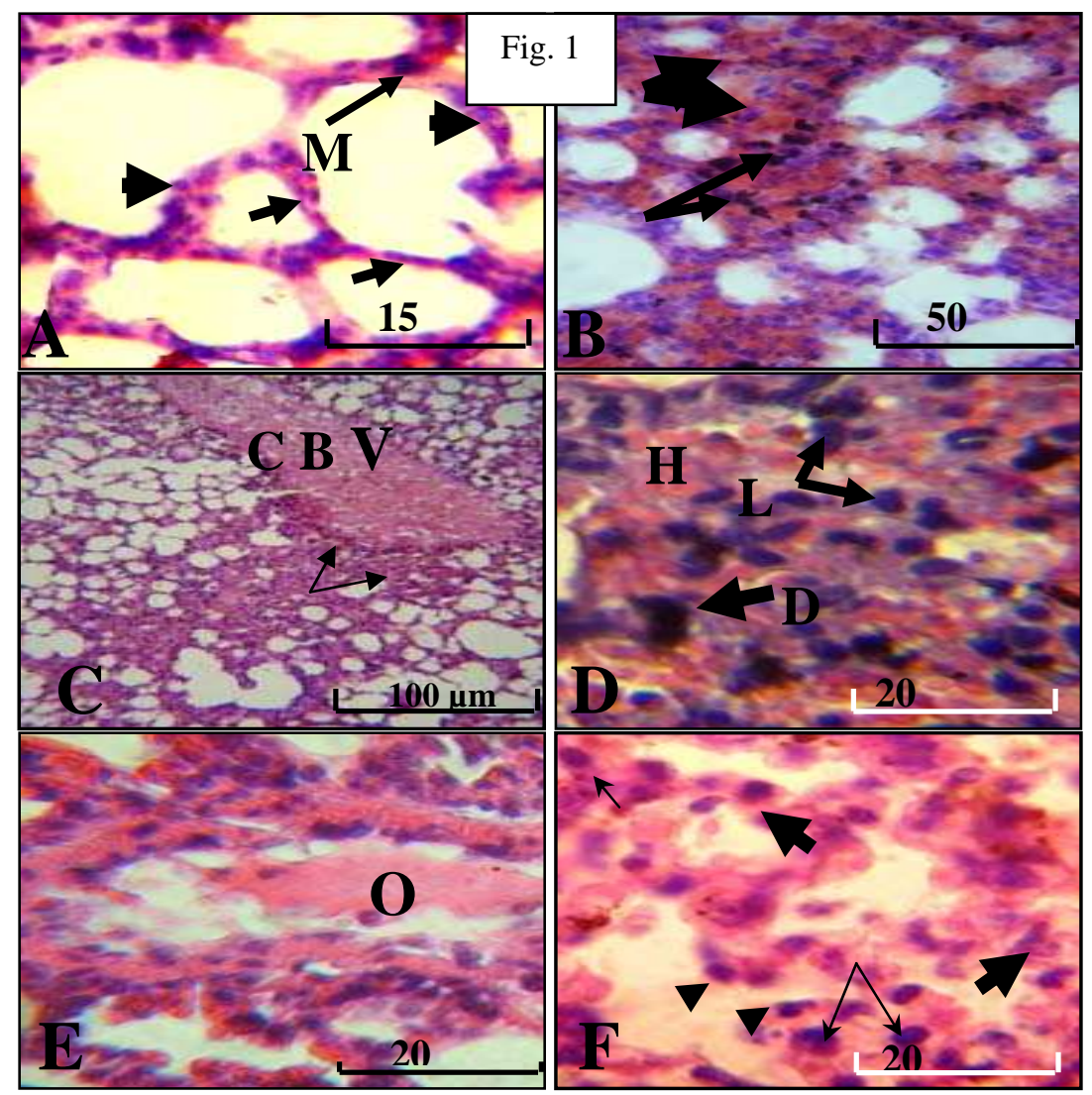

Figure 1 - A - T. S. of control guinea pig lung showing normal alveoli; squamous cells (thin arrows), secretory cells (thick arrows) and macrophages (M.). (H\&E stain).

B - T. S. of the lung of TI showing haemorrhage (thick arrows) and increase of dust cells (thin arrows) between the alveoli. (H\&E stain).

C - T. S. of the lung of TII showing congested blood vessel (CBV) and infiltration of lymphocytes (thin arrows). (H\&E stain).

D - T. S. of the lung of TII showing haemorrhage (H), and increases of lymphocytes (L) and dust cells (D). (H\&E stain).

E - T. S. of the lung of TIII showing oedema (O). (H\&E stain).

F - T. S. of the lung of TIII showing increase of macrophages (thin arrows), pyknotic nuclei (short arrows) and necrotic cells (thick arrows). (H\&E stain).

\section{Intestine}

The normal villi of the small intestine (jejunum) of guinea pig are shown in Fig. (2 A). Inspected intestinal sections obtained from the animals treated with $1 / 20 \mathrm{LD}_{50}$ of diazinon revealed slight changes. These changes were represented mainly in the infiltration and hypertrophy of the lymphocytes (Fig. 2 B). The treatment with $1 / 10$ $\mathrm{LD}_{50}$ of the insecticide resulted in haemorrhage in the submucosa, aggregation of lymphocytes and erosion in the lining epithelium of the small intestine of the treated animals specially in the duodenal area (Figs. $2 \mathrm{C}$ and D). Also, the normal pattern of villi was mostly ill defined.
Sever histological effects were observed in the small intestine post treatment with the high dose $\left(1 / 5 \mathrm{LD}_{50}\right)$. The erosions were perceptive in different parts of the intestine and the cells of the lining epithelium and crypts exhibited pyknotic nuclei. In addition, necrotic cells and degenerated areas were greatly encountered (Figs. $2 \mathrm{E}$ and F).

\section{Histochemical effect \\ Total proteins}

The total proteins were indicated as blue colour with bromphenol blue stain, the average of total proteins in the lung of control animals recorded 1.576 (Fig. $3 \mathrm{~A}$ and Table 2). This average 
recorded 1.408, 1.0 and 0.805 in TI, TII and TIII respectively. This decrease was significant with the high dose only; the percentages of decrease recorded 10.66, 36.55 and $48.92 \%$ in TI, TII (Fig. 3 B) and GIII (Fig. 3 C), respectively. The average of the total proteins in the intestine of the control animals was 2.066 (Fig. 4, A and Table 2). This exhibited significant decreases in all insecticide treated groups. The percentage of changes recorded $-31.12,145.15$ and $-65.97 \%$ in TI, TII (Fig. 4 B) and TIII (Fig. 4 C), respectively.

\section{Polysaccharides}

The polysaccharide materials were indicated as magenta colour with PAS stain, the average of carbohydrates in the control lung recorded 1.028 (Fig. 3 D). The treatment with low doses of diazinon induced significant reduction in the polysaccharides content in TII (Fig. $3 \mathrm{E}$ ) and TIII (Fig. $3 \mathrm{~F}$ ) while in TI this reduction was nonsignificant. The percentages of these reduction recorded $9.34,24.81$ and $28.79 \%$ in TI, TII and TIII, respectively (Table 2). The average of polysaccharides in the intestine of the control animals recorded 1.866 (Fig. 4 D). This average recorded significant reduction in all diazinontreated groups in comparison with the control. The percentage of change reached -46.94 in TII (Fig. 4 E) and $-63.29 \%$ in TIII (Fig. 4 F).

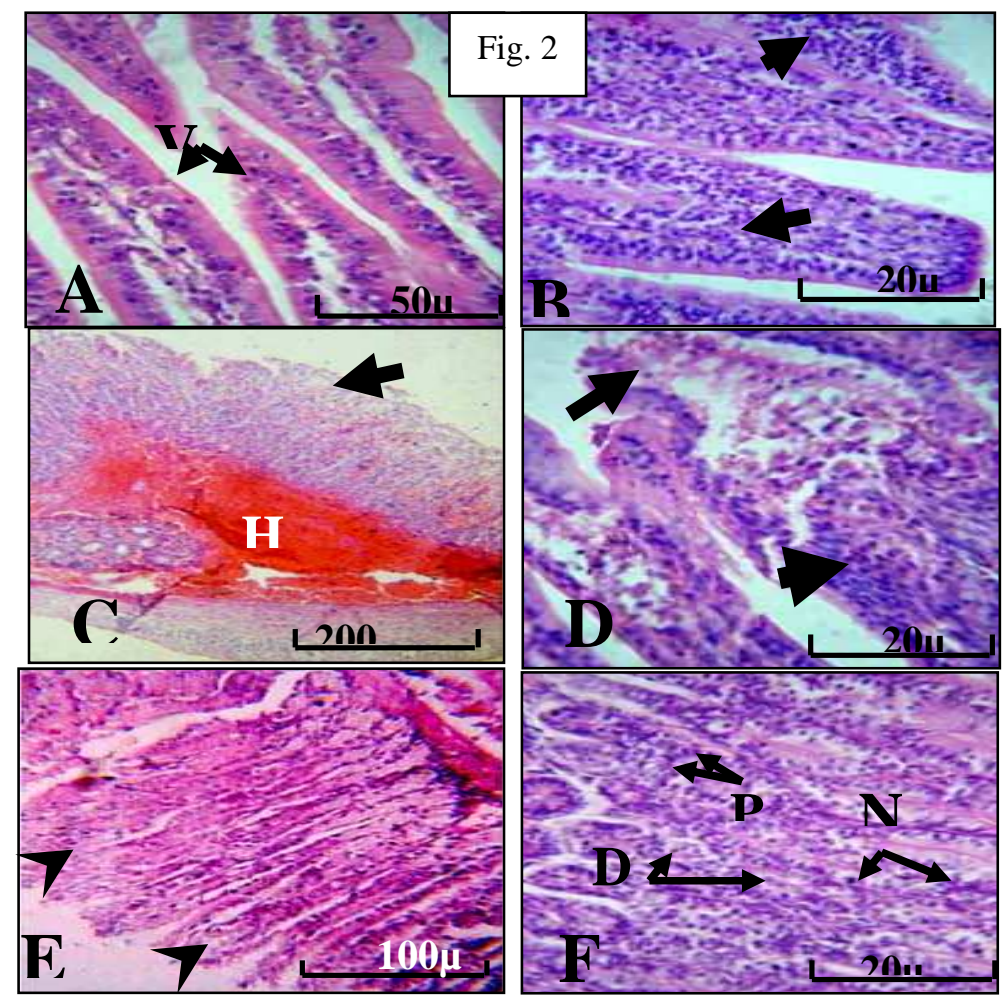

Figure 2 - A - T.S. of control guinea pig small intestine showing normal villi (V). (H\&E stain). B - T.S. of the intestine of TI showing infiltration of lymphocytes within the villi (arrows). (H\&E stain).

C - T.S. of the intestine of TII showing haemorrage in the duodenal submucosa and mucosa $(\mathrm{H})$ and erosion in the mucosa (arrow) and disarray in the villi. (H\&E stain).

D - T.S. of the intestine of TII showing erosion (tall arrow) and aggregation of lymphocytes (short arrow). (H\&E stain).

$\mathbf{E}$ - T.S. of the intestine of TIII showing disarray in the villi pattern (arrows). (H\&E stain).

F - T.S. of the intestine of TIII showing pynknosis (P), necrosis (N) and degenerated area (D) in the intestinal crypts. (H\&E stain). 
Table 2 - Mean \# optical density (M.O.D.) values relative to histochemical reactions in the lung and intestine of control and treated animals.

\begin{tabular}{|c|c|c|c|c|c|c|c|c|c|}
\hline & & \multicolumn{4}{|c|}{ Total Proteins } & \multicolumn{4}{|c|}{ Polysaccharides } \\
\hline \multirow{6}{*}{ Lung } & & Control & TI & TII & TIII & Control & TI & TII & TIII \\
\hline & Average & 1.576 & 1.408 & 1.0 & 0.805 & 1.028 & 0.932 & 0.773 & 0.732 \\
\hline & $\mathrm{SD}$ & 0.408 & 0.390 & 0.313 & 0.204 & 0.116 & 0.215 & 0.132 & 0.095 \\
\hline & SE & 0.166 & 0.159 & 0.128 & 0.083 & 0.047 & 0.087 & 0.054 & 0.038 \\
\hline & $\mathrm{t}$ test & & 0.2076 & 0.034 & 0.0049 & & 0.139 & 0.0038 & $9.12 \mathrm{E}-05$ \\
\hline & & & N S. & N S. & S. & & N S. & $\mathrm{S}$. & $\mathrm{S}$. \\
\hline \multirow{7}{*}{ Intestine } & $\begin{array}{l}\text { Percentage of } \\
\text { change }\end{array}$ & & $-10.66 \%$ & $-36.55 \%$ & $-48.92 \%$ & & $-9.34 \%$ & $-24.81 \%$ & $-28.79 \%$ \\
\hline & Average & 2.066 & 1.423 & 1.133 & 0.703 & 1.866 & 1.416 & 0.990 & 0.685 \\
\hline & $\mathrm{SD}$ & 0.393 & 0.489 & 0.593 & 0.274 & 0.314 & 0.314 & 0.226 & 0.098 \\
\hline & $\mathrm{SE}$ & 0.160 & 0.199 & 0.242 & 0.112 & 0.128 & 0.128 & 0.092 & 0.040 \\
\hline & $\mathrm{t}$ test & & 0.0052 & 0.0055 & 0.0002 & & 0.0076 & 0.0032 & 0.0001 \\
\hline & & & S. & S. & S. & & S. & S. & S. \\
\hline & $\begin{array}{l}\text { Percentage } \\
\text { of change }\end{array}$ & & $-31.12 \%$ & $-45.15 \%$ & $-65.97 \%$ & & $-24.12 \%$ & $-46.94 \%$ & $-63.29 \%$ \\
\hline
\end{tabular}

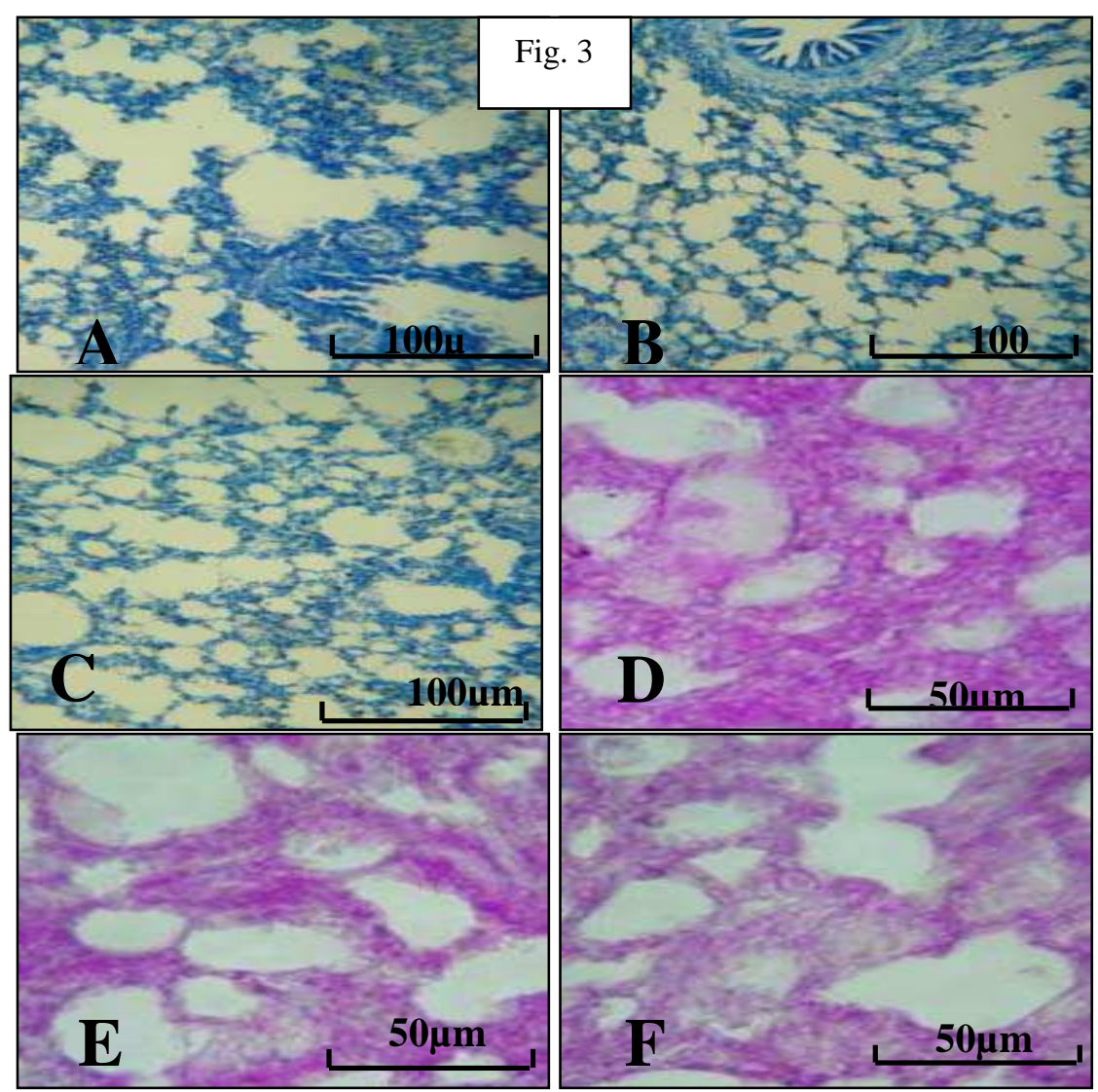

Figure 3 - A - T. S. of control guinea pig lung showing normal content of the total protein (Bromphenol blue stain).

B - T. S. of the lung of TII showing reduction in the total protein content. (Bromphenol blue stain).

C - T. S. of the lung of TIII showing reduction in the total protein content. (Bromphenol blue stain).

D - T. S. of control guinea pig lung showing normal content of the polysaccharides content (PAS stain).

E - T. S. of the lung of TII showing reduction in the polysaccharides content (PAS stain).

F - T. S. of the lung of TIII showing reduction in the carbohydrates content (PAS stain). 


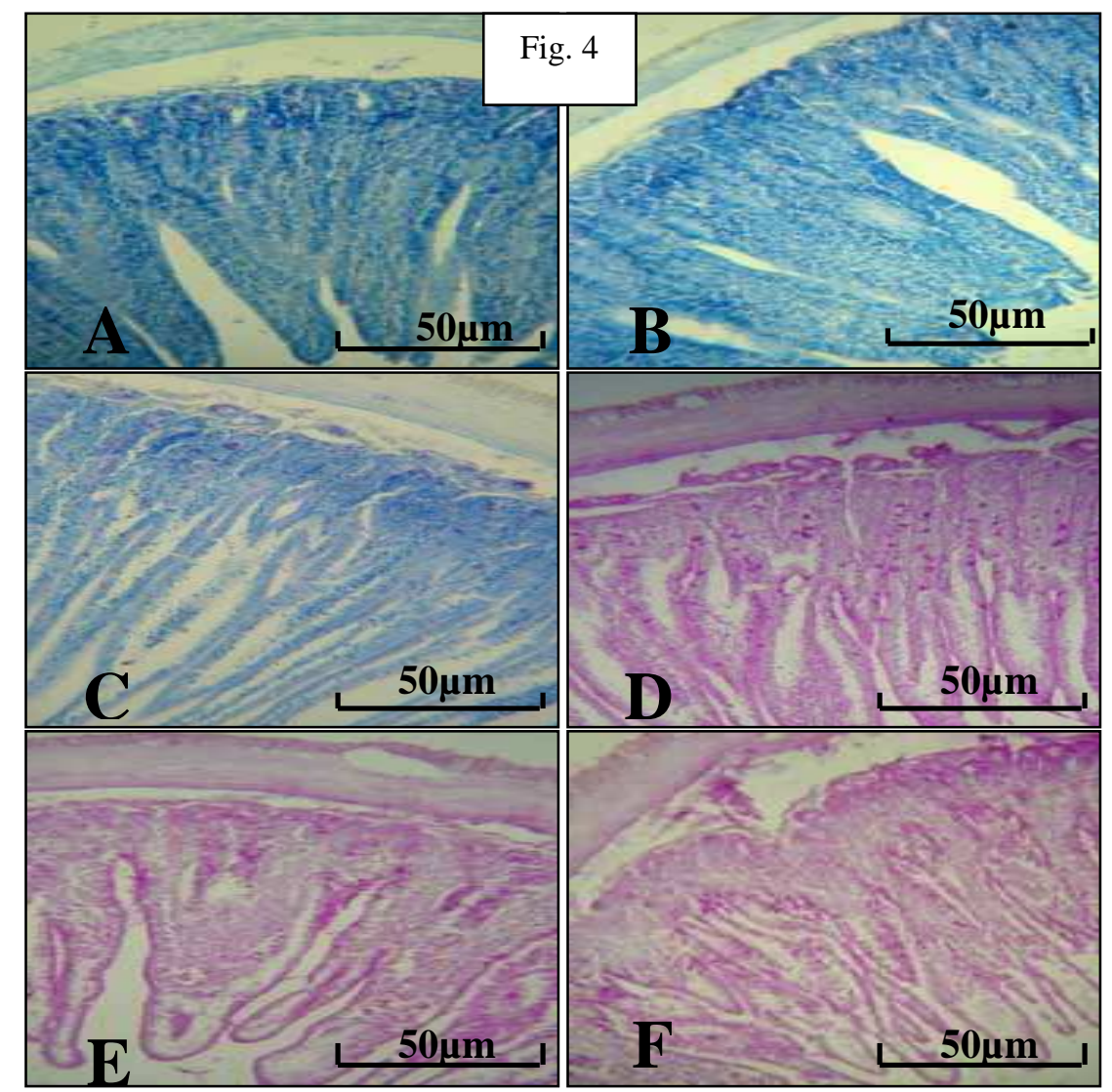

Figure 04 - A - T. S. of the small intestine of control guinea pig showing the normal content of the total proteins. (Bromphenol blue stain).

B - T. S. of the small intestine of TII showing reduced total proteins content. (Bromphenol blue stain).

C - T. S. of the small intestine of TIII showing reduced total proteins content. (Bromphenol blue stain).

D - T. S. of the small intestine of control guinea pig showing the normal content of the polysaccharides. (PAS stain).

E - T. S. of the small intestine of TII showing depletion of the carbohydrates content. (PAS stain).

F - T. S. of the small intestine of TIII showing depletion of the polysaccharides content. (PAS stain).

\section{DISCUSSION}

The exposure to diazinon is a complicated subject. The organophosphates are efficiently absorbed by inhalation, ingestion and skin penetration and this exposure by the multiple routes can lead to serious additive toxicity (Reigart and Roberts, 1999). The $\mathrm{LD}_{50}$ value of diazinon orally administration in male guinea pigs (Cavia porcellus) recorded in the present study was $213 \mathrm{mg} / \mathrm{kg}$ body weight. Similarly, the $\mathrm{LD}_{50}$ calculated was close to that obtained by Worthing and Hance (1991) i.e. 210 $\mathrm{mg} / \mathrm{kg} \mathrm{B} \mathrm{W}$ of guinea pig and WHO (1999) i.e. $200 \mathrm{mg} / \mathrm{kg} \mathrm{B} \mathrm{W}$ of rat. Otherwise, the $\mathrm{LD}_{50}$ was
300 to $400 \mathrm{mg} / \mathrm{kg}$ for technical grade diazinon in rats (Gallo and Lawryk, 1991).

However, considering the classification of the toxicity of the substances (Matsumura, 1975), extremely toxic substance had $\mathrm{LD}_{50}$ less than $1 \mathrm{mg} / \mathrm{kg}$, highly toxic substance from $1-50 \mathrm{mg} / \mathrm{kg}$, moderately toxic substance between $50-500 \mathrm{mg} / \mathrm{kg}$ and relatively harmless $15 \mathrm{~g} / \mathrm{kg}$ and above. Based on this classification, diazinon appeared slightly toxic in the male guinea pig using oral route of administration. The symptoms that appeared here were indicative of the toxicity of diazinon on the central nervous system in accordance with Dede (1992). Also, the convulsion as a neurological sign recorded in most animals in the current study was 
in agreement with Smith (1991) and Dede and Dogara (2004). In this respect, Manna et al. (2004 a) attributed the convulsion, produced due to the exposure to insecticides, to the enhancement in lactic acid production. The increased respiratory rate could be a direct result of lung reaction to diazinon (Dorland, 1977) or the effect of the chemical on the respiratory centre in the reticular formation (Dede and Simini 2001). However, Gallo and Lawryk, (1991) reported that in the animals, diazinon converted to diazoxon which was a strong cholinesterase inhibitor.

The xenobiotics can adversely affect the lung, resulting in respiratory insufficiency (Guyton, 1976). The present results showed that the exposure to the sub lethal doses of diazinon insecticide induced dose-dependent histopathological lesions in the lung of guinea pig. These lesions were mostly represented in the infiltration of the macrophages and mononuclear cells, haemorrhage, congested blood vessels, oedema, pyknosis and necrosis. Then, alterations in the lung tissue observed in the present investigation, as a consequence of diazinon insecticide application, showed similarity and conforms those recorded by several authors in various experimental animals exposed to organophosphorus insecticides (Williams and Sandler, 2001; Alavanja et al., 2004 and Hemmati et al., 2005). Giray et al. (2001) discussed that such these histopathological changes could be attributed to the decreases in the antioxidant status of the animal body induced by the chemical.

The congestion of the lung vasculature which was noticed in the present investigation, could be due to the excessive blood in venous system, which increased blood pressure in the veins and capillaries. This might exert undue pressure on the neighboring structures. This is usually accompanied be a diminished blood supply, thus become subjected to malnutrition, deficient oxygenation and the accumulation of the excretory products (Haschek and Rousseaux, 1991).

Latuszynska et al. (1999) showed that the dermal application of the chlorpyrifos, organophosphorus insecticide, induced the foci of various sizes consisting of lymphatic tissue and foam cells in the interalveolar septa in rats. Fryer et al. (2004) demonstrated that the organophosphate insecticides could cause airway hyperactivity in the absence of AChE inhibition by decreasing neuronal receptor function. Alavanja et al. (2004) reported that different pesticides including diazinon have been found to be significantly associated with the lung cancer.

Results of the present study revealed that low doses of diazinon insecticide caused different histopathological changes in the small intestine of male guinea pig. These changes were manifested in infiltration and hypertrophy of the lymphocytes, haemorrhage in the submucosa, erosion in lining epithelium, pyknotic nuclei and necrotic cells. These lesions were more evident with the high doses. Similarly, desquamation, haemorrhage and necrosis of the epithelial cells of the stomach and intestine were noticed post $\alpha$-cypermethrin insecticide oral administration in rats (Manna et al., 2004 a). In vitro study showed that the cultured intestinal and colonic cell proliferation was decreased by diazinon insecticide (Greenman et al., 1997). In contrary of the present results, Zaleska-Freljan et al. (1983) reported that promfenvinphos organophosphate pesticide induced no changes in the stomach, small and large intestine of mice.

It has been suggested that the tissue proteins and polysaccharides were generally inhibited in various animals to which organophosphate was applied. The present results indicated that low doses of diazinon caused significant reduction in both the proteins and carbohydrates in a dose dependent manner in the lung and small intestine of guinea pig. Ritter (1977) reported that the cell necrosis could be either due to progressive degenerative action of the intracellular enzymes of the injured cells or to a metabolic disturbance and inhibition of synthesis needed for the DNA and hence the protein synthesis for the growth and maturation of the cells.

Disturbed carbohydrates metabolism following diazinon treatment was also noticed by Lomte and Mule (1992). Sheela and Muniandy (1992) reported significant decreases in the protein, carbohydrate and lipid content of muscle and liver at different sub lethal concentrations of the organophosphate insecticide dimethoate in rats. Anusha-Amali et al. (1996) revealed that the sub lethal effects of organophosphorus pesticide quinalphos induced the depletion in carbohydrate, protein and lipid contents in all the tissues and this depletion was observed to be concentration dependent.

Generally, the reduction in the carbohydrate and protein contents observed in the present study could be due to the release of the hydrolytic enzymes from ruptured lysosomes under the effect 
of the toxic agents, as suggested by Sivaprasado et al. (1993).

In conclusion, the present findings have shown that the sub lethal doses of diazinon insecticide might cause histopathological lesions in various degrees in the lung and small intestine of male guinea pigs. In addition, these findings have shown that diazinon caused depletion in the total proteins and carbohydrates in the aforementioned tissues and these effects were correlated with the concentration of the organophosphate. Hence, efforts should be made to reduce the pesticides use and the development of chemical free alternatives. Far more consideration should be given to the farmers and consumers. In order to start to reduce the present high-level agrochemicals use and contamination, the government policy should motivate farmers to adopt the effective integrated pest management strategies.

\section{REFERENCES}

Alavanja, M.; Dossemeci, M.; Samanic, C.; Lynch, F.; Knott, C.; Barker, J.; Hoppin, J.; Sandler, D.; Thomas, K. and Blair, A. (2004) Pesticides and lung cancer risk in the agricultural health study cohort. Am. J. Epidemiol.; 160: 876-885.

Anusha Amali, A.; Cyril: Arun Kumar, L.; Elizabeth Jayanthi, F. X. and Selvanayagam, M. (1996) Quinalphos induced biochemical anamolies in Cirrhinus mrigala (Ham.). J. Environ. Bio. 17 (2): 121- 124.

Behren, W. and Karber, G. (1953) Determination of LD $_{50}$. Arch. Exp. Path. Pharm.; 2:177-272.

Dede, E.B. (1992) Effect of lindane pretreatment on dichlorvos toxicity in vitro and in vivo. $\mathrm{Ph}$. D Thesis, ABU, Zaria, Nigeria.

Dede, E.B. and Chike, C.P. (2000) Histopathological study of chronic effect of dichorvos on rat liver and small intestine. J. Appl. Sci. and Environ. Mange.; 4: 33-36.

Dede, E.B. and Simini, A. (2001) Electroencephalographic study of the interaction between dichlorvos and lindane in rat brain. Nig. J. Neur.; 4: 21-26.

Dede, E.B. and Dogara, F.M. (2004) The acute toxicological effects of gammalin 20 on the lung and pancreas of guinea pig. J. Appl. Sci. and Environ. Mange.; 8 (1): 33- 35.

Dinham, B. (2005) Prolonged exposure to some agricultural pesticides may increase the risk of lung cancer in agricultural workers. Evidence-Based Healthcare and Public health.; 9 (3): 203- 205.
Dorland, S. (1977) Dorland pocket medical dictionary. W.B. Saunder, London pp. 510.

EPA (1999) Quantitative usage analysis for diazinon. Washington, U.S.A. DC, Jan. 29.

Fryer, A.D.; Lein, P.J.; Howard, A.; Yost, B.; Backles, R. and Jett, D.A. (2004) Mechanism of organophosphate insecticide-induced airway hyperreactivity. Am. J. Physiol. Lung Cell Mol. Physiol.; 286 (5): 963-969.

Gallo, M.A. and Lawryk, N.J. (1991) Organic phosphorus pesticides. In Handbook of Pesticide Toxicology. Hayes, W .J .Jr. and Laws, E. R.; Eds. Academic Press, New York.

Giray, S.; Gurby, A.; and Hinealm, F. (2001) Cypermethrin induced oxidative stress in rat brain and liver is prevented by Vit-E or allopurinol. Toxicol. Lett.; 118: 139-146.

Greenman, S.; Rutten, M.; Fowler, W.; Scheffler, L.; Shortridge, L.; Brown, B.; Sheppard, B; Deveney, K.; Deveny, C. and Trunkey, D. (1997) Herbicide/pesticide effect on intestinal epithelial growth. Environ. Res.; 75 (1): 85-93.

Guyton, C.A. (1976) Textbook of medical physiology. $8^{\text {th }}$ Edition pg. 506-521.

Haschek, W. M. and Rousseaux, C. G. (1991) Hand book of toxicological pathology. Academic Press, London and New York.

Hemmati, A.A.; Nazari, Z.; Ghafurian, N.; Ranjbari, N. and Darabi, B. (2005) Study of the effects of sodium cromlyn on levels of TNF $\alpha$, IL1- $\beta$ and collagen in the paraquat induced pulmonary fibrosis in rat. Toxicol. Lett.; 158.

Humason, G. L. (1979): Animal Tissue Techniques. $2^{\text {nd }}$ ed. Freeman, W.H and company, pp: 661.

Latuszynska, J.; Luty, S.; Halliop, J.; Przylepa, E.; Tochman, A.; Obuchowska, D. and Korczak, E. (1999) Studies toxicity of dermally-absorbed nurelled D 550EC preparation. Ann. Agric. Environ. Med. ; 6: 151-159.

Lomte, V. S. and Mule, M. B. (1992) Effect of rogor (dimethoate $30 \%$ EC) on glycogen content of freshwater snail Welanoides tuberculatus. Proc Acad. Environ Bio. 1: 101- 108.

Manna, S.; Bhattacharyya, D., Basak, D. and Mandal, T. (2004 a) Single oral dose toxicity study of $\alpha$ cypermethrin in rats. Indi. J. Pharmacol.; 36 (1): 25 28.

Manna, S.; Bhattacharyya, D., Mandal, T. and Das, S. (2004 b) Repeated dose toxicity of alfa-cypermethrin in rats. J. Vet. Sci.; 5 (3): 241-245.

Matsumura, F. (1975) Toxicology of insecticide. $2^{\text {nd }}$ ed. Plenum Press New York p 4-6.

Mazia, D.; Brewer, P. A. and Affert, M. (1953): The cytochemical staining and measurement of protein with mercuric bromphenol blue. Biol. Bull. 104: 5767. 
Poet, T.S.; Wu, H.; Kousba, A. and Timchalk, C. (2003) In vitro rat hepatic and intestinal metabolism of organophosphate pesticide chlorpyrifos and diazinon. Toxicol. Sci.; 72 (2): 193-200.

Purdey, M. (1994) Are organophosphate pesticides involved in the causation of Bovine Spongiform Encephalopathy (BSE)? Hypothesis based upon a literary review and limited trails on BSE cattle. $J$. Nutr. Med.; 4: 43-82.

Reigart, J.R. and Roberts, J.R. (1999) Recognition and management of pesticide poisoning. Fifth ed. Washington, D.C. U.S. EPA p. 34-38.

Ritter, E. J. (1977) Altered Biosynthesis. In: Handbook of Teratology. Vol.2 Plenum Press, New York.

Sendecor, G. W. (1987): Statistical Methods $6^{\text {th }}$ ed. Lowa State Univ. Press.

Sheela, M. and Muniandy, S. (1992) Impacts of pesticide dimethoate on the body consumption, add and alkaline phosphatases in different tissues of the fish, Lepidocephalichthys thermalis. Env. Eco. 10 (1): 220-223.

Sivaprasado, K.; Sombasiva, K. and Ramona, K. (1993) Effect of parathion on tissue ionic changes in fish Channa punctatus. Geobios (Jodhpvr) 10 (2): 60- 62.

Smith, A.G. (1991) Handbook of pesticide toxicology. Hayes W.J.

Wagner, S. L.; Durand, L. R.; Inman, R. D.; Kiigemagi, U. and Deinzer, M. L. (1991): Residues of pentachlorophenol and other chlorinated contaminants in human tissues: Analysis by electron capture gas chromatography and electron capture negative ion mass spectrometry. Arch. Environ. Contam. Toxicol. 21: 596- 606.
Ware, G.W. (2000) The pesticide book. Fresno, CA: Thomson Publications. pp. 181.

Williams, M.D. and Sandler, A.B. (2001) The epidemiology of lung cancer. Cancer Treat. Res.; 105: 31-52.

WHO (1999) Recommended of pesticides by hazard and guidelines to classification. International Programme on Chemical Safety. Rev. 1.

Worthing, C.R. and Hance, R.J. (1991) The pesticide manual. 9th. ed. BLCP London, England.

Zaleska-Freljan, K.; Kosicka, B. and Zbiegieni, B. (1983) The histological changes in some organs of the laboratory mice after intragastric given bromfenvinphos and mixture of bromfenvinphos with methoxychlor. Pol. J. Pharmacol. Pharm.; 35 (3): 185-193.

Received: December 22, 2005; Revised: September 19, 2006; Accepted: July 21, 2008. 